\title{
THE ADDRESSEE-SHIP OF ANCIENT GREEK NOVELS: PORTRAYING PICTURES, DEBUNKING MYTHS
}

\author{
MARC GANDARILLAS \\ University of Florida \\ m.gandarillascot@ufl.edu \\ ORCID: 0000-0002-7393-2613
}

\begin{abstract}
This paper delves into the question of the potential addressees of ancient Greek novels. After shedding some light on the matter (based on ancient sources which account for the sociocultural underpinnings of the new genre), a classification is established in an attempt to provide a deeper understanding of alleged homogeneity in readership. The entire bibliography demonstrates a discontinuation in the conception prevalent decades ago, which, based on subjective and anachronistic interpretations, would find reinforcement in the silence of ancient sources. To make matters more intricate, the surviving information regarding how the novel was viewed in ancient times appears not to point to a prestigious status thereof. All things considered, should these presumptions alone lead us to consider the novel as a low-quality genre in terms of literary and stylistic standards? Ancient Greek novel might well be one of those cases in which literary or cultural creations have called for reassessment and revaluation several centuries following their conception.
\end{abstract}

KEYWORDS: ancient Greek literature, Ancient Greece, ancient Greek novel, literary addressees, novelistic genre readership.

\section{PRELIMinARY NOTE}

This paper explores the issue of who might have been the potential addressees of ancient Greek novels. I will begin by shedding light on the matter based on ancient sources related to the sociocultural underpinnings of the novelistic genre. A typological classification will follow, prior to providing some clarification on the homogeneity of such potential addressee-ship, be it a community of readers or otherwise. All the references consulted appear to have abandoned conceptions of the genre which used to be commonplace until some decades ago. Based on subjective and anachronistic interpretations - and largely fueled by the troubling silence found in most ancient sources - the ancient Greek novel has a consistent history of being regarded as a minor genre. Just to make matters worse, contemporary accounts on the genre do not point exactly to a high-profile status thereof. This has led researchers to question the legitimacy of characterizing Ancient Greek novels as a low-quality genre (at least in terms of literary and stylistic standards). Initial suspicions have pointed to the fact that these pieces might be one of those literary specimens which are still calling for assessment and revaluation, even after those have undergone a lengthy history of contempt. 
Some past scholars have been known for incorporating unwanted biases by establishing a set of generalizations which are based solely on the exiguous corpus of the genre preserved to date. Still, we know for a fact that the novels used to constitute a highly versatile and mimesis-prone genre, which equally seems to apply to the intrageneric and extrageneric levels. At the time, "classical" standards appear to have been abandoned for a while. However, in spite of the Roman political precedence, Greek novelists like to take pride in the preceding literary legacy, which is still pervasive in their works. In delving into the potential addressee-ship of the genre under study, an understudied group of controversial pieces appears to hold the key to multiple answers. Within the corpus of "ideal" novels, these include the so-called "early" or "pre-Sophistic" novels, which encompass the works of Chariton of Aphrodisias and Xenophon of Ephesus, as well as a number of highly fragmented passages.

In the search for a stereotype of "intended" readership, ${ }^{1}$ it is common to consider the role of women as potential readers. On this note, I will reflect on some relevant changes on the societal role of women back in the day, and, relatedly, I will venture some explanations which may account for the preeminence of women as a leitmotiv in the novels.

Last but not least, I will tackle the question of how feasible it might have been for novels to be conceived and subsequently performed by means of oral dissemination. In this new context, heir to the classical tradition, it might not be unreasonable to assume that orality could still somehow intertwine with literary production. Relatedly, for the title of this paper, the word addressee-ship has been chosen quite intentionally over readership.

\section{THE EMERGENCE OF NOVELS IN THE LIGHT OF A NEW CULTURAL PERIOD}

Traditionally, several sociocultural changes are mentioned in connection with the emergence of the Hellenic period. Such changes encompass shifts in the citizens' way of life as they represent a break from prior mindsets and community values. To delve into the motivational underpinnings of the genre under study, it is essential to carefully analyze for contextual clues and, relatedly, view the novels as a societal response to new literary needs and tastes, based in turn upon an emerging sociocultural structure, as well as an innovative lens through which the surrounding reality is viewed and interpreted.

Modern scholars have underscored the precedence of individualism over comradeship during the Hellenistic period. Likewise, homeland identity appears to have lost relevance when compared to the Classical period. A representative example of this is provided by Heliodorus' Aethiopica, whose characters are presented in the account as ätoто (i.e., 'displaced,' lit. 'from nowhere'). Other terms occur which are associated with the semantic field of "uprooting" (e.g.,

\footnotetext{
${ }^{1}$ I am here using a term coined by Bowie (1996).
} 
$\dot{\alpha} \lambda \eta \tau \eta \zeta, \pi \lambda \alpha v \tilde{\alpha} v)$. In the Hellenistic period, the classical idea of pólis has collapsed and consequently given way to a worldly culture. Focused on large metropolises, the new reality shows travel as widespread, with individuals increasingly becoming sources of conflicting desires and centrifugal tendencies. Relatedly, the values of social cohesion and land attachment (typically found in Athens' traditional myths of autochthony) are gradually abandoned by individuals who appear to undergo a de-politicization process (in the etymological sense of the term) -more and more, the $\pi \alpha \tau \rho i \varsigma$ or 'homeland' is no longer related to the birthplace, but rather to one's temporary location. ${ }^{2}$ Needless to say, such new situation permeates the novels by means of a number of allegorical stereotypes which are either situational or associated with a particular character in the plot. The literary productions under study are no longer to fulfil social cohesion expectations within the pólis (cf. ancient epic, theater), but will rather pursue the individual intimate enjoyment. While this situation seems to hold true for Antioch and Alexandria, it does not appear to find a suitable fit with the urban centers in Asia Minor, such as Pergamon (Bowie 1996). In the later, tradition and belonging still remain strong values, which compares to the norm found for the Classical póleis.

Few urban centers in Asia Minor experienced a population growth remotely similar to that of Classical Athens. With this area (esp. its western portion, eastern Aegean $^{3}$ ) typically considered as the birthplace of the novel, it might not be completely accurate to credit the aforementioned changes for the new period with the emergence of the novelistic genre. Acknowledging some degree of incoming depoliticization, not only does the new genre no longer bear a political, "pragmatic" purpose attached, but rather appears to pursue a fully literary, arsgratia-artis goal. This relates to either reader identification (i.e., readers can easily find their own reflection in the characters) and compensation (i.e., readers can temporarily "escape" their worries as they fantasize about adventure and romance). The action always remains well within the boundaries of verisimilitude, thus abiding by the $\tau \dot{o}$ cikós principle, in spite of large doses of idealism. Novels from the Sophistic period demonstrate their willingness to perfect fictional techniques, as these are consistently used as a hiding veil for the actual purposes of the author. An interesting example is found in Xenophon's Cyropaedia, which serves a twofold purpose - both philosophical and educational. ${ }^{4}$ Starting in the Byzantine era (not prior to this), novels would start to bear a strong educational or pedagogical component attached.

\footnotetext{
${ }^{2}$ An interesting source of information and reflection may be found in Whitmarsh (2001) and Perry (1937).

${ }^{3}$ It is possible to trace the geographic framework of the "intended readership" based on certain clues from the early works (e.g., Callirhoe, Ninus).

${ }^{4}$ Starting in the Byzantine era - not prior to this period- novels would start to bear a strong educational component attached to them.
} 
Some claims have been raised that increased literacy levels at the time may have prompted the emergence of a "book culture," as opposed to an oral one. However, evidence suggests that there was never a presence of a "mass" literacy, nor was orality completely abandoned (Hägg 1994, Morgan 1995). Additionally, this statement appears to be restricted to the type of novels labeled as "ideal," which encompass romance, travel, and adventure-themed novels. Such novels constitute the most broadly documented group within the genre. In addition to those, evidence from papyraceus fragments suggests the existence of multiple "unsettling-themed" novels which might not be a good fit with said idealism.

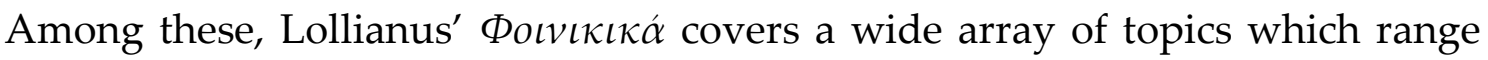
from sex to human sacrifice to even anthropophagy. As will be covered later on, taxonomizing the novels in subgenres reveals several discrepancies when it comes to identifying a potential readership for each of those subgenres.

\section{THE STATUS OF NOVELS IN ANTIQUITY. LITERARY CRITICISM AND INFLUENCES}

\subsection{Contemporary references}

As we delve into the issue of the potential readership of the novel, we are soon faced by the constraints posed by the silence of contemporary references. While it is possible that genre-related theorization became lost at some point, it is most likely that this never existed. A lack of theoretical, critical interest appears to be widespread during extended periods in Antiquity (West 2003, Hunter 2008, Morgan 1995). Even when some degree of theorization is found, the reputation of novels appears to be far from favorable.

An example of this is found in Philostratus (Epist. 66), who claims that Chariton was destined to eventually fall into oblivion:

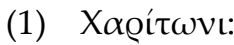

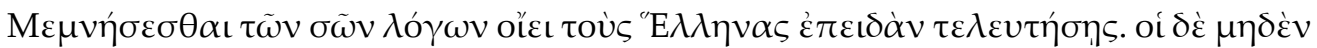

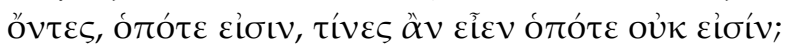

'To Chariton:

Do you truly believe that Greeks will recall your words once you are dead? Those who are nobodies in life, what do they become once they are dead?'

The reference above can be considered of the utmost relevance, since it provides the earliest evidence of the fact that Chariton was known beyond the Egyptian borders. In Julian (Epist. 89 301b, which is interestingly addressed to some "Chariton"), criticism of the genre is found that targets the portrayal of erotism and fictionality. The author brands the genre as some set of "dramatic works" or "plays." To this respect, it is important to remember that Julian once banned the priests in Asia Minor from reading "past fictions that come in the form of historical accounts, tales of éros, and the like." On the other hand, Macrobius calls the works of Petronius and Apuleius a "waste of time," besides 
instances of "stories stuffed with fictional events in which some lovers play the lead," which "only aim at being pleasant to the ears" (Comm. in Somn. Scip. 12 7). Such annihilating criticism was still commonplace as recently as four decades ago. Until then, the genre was believed to have been conceived with a target readership in mind who came from below-average educational backgrounds - as opposed to the readership of classical genres. With this conception having been overridden nowadays, the issue under study appears to call for reformulated questions and new insights.

Sometimes it is possible to find criticism of the genre within the genre itself. Heinze (1899) mentions Petronius' Satyrica as a derisive parody of the "ideal" Greek novels. Conceiving the novel as a homogeneous genre is most likely not a recent approach. Some piece of literary theory might have existed at some point (a novel-focused treatise similar to Aristotle's Poetics). In the ideal novels, an intrageneric tradition of mimesis is frequently followed, which provides some degree of unity across works. For example, Xenophon tends to emulate Chariton, even if the latter's work is regarded as technically inferior to the former's. Also, Sophistic authors (with Heliodor as the prime example) appear to be inspired by these sources, in an attempt to take the genre to its utmost expression through emulation. It is, however, highly questionable that the novels outside of this select group would have been regarded as a part of the same genre or literary group. In more recent times, based on a wide range of criteria, literary theorists tend to increasingly support stances of unity within the novelistic genre. In Antiquity, such lack of unity is reinforced by the fact that there was not a generic label to designate such sets of stories. Even as both Greek novelists themselves and, in the 11th century, Photios like to refer to these literary creations as $\pi \lambda \dot{\alpha} \sigma \mu \alpha \tau \alpha$, this term apparently has not undergone any semantic specialization process. Instead, it is oftentimes used with its basic meaning (i.e., 'image,' 'figure'), as a deverbal noun (from $\pi \lambda \dot{\alpha} \sigma \sigma \omega \mathrm{o} \pi \lambda \dot{\alpha} \tau \tau \omega$, 'to model'), as opposed to $\pi \circ \iota \eta \dot{\sigma} \varsigma$ (from $\pi \circ \iota \varepsilon \dot{\varepsilon} \omega$, 'to build,' 'to create'). A number of alternative terms are also found which show no evidence whatsoever of lexical technification as terms from the field of literary theory. In the $\sigma \varphi \rho \alpha \gamma i \varsigma$ which concludes his Aethiopica, Heliodor employs the term $\sigma \dot{v} \gamma \gamma \rho \alpha \mu \mu \alpha$. Other terms are $\mu \tilde{v} \theta o \varsigma, \delta \rho \tilde{\alpha} \mu \alpha$, and $\varepsilon \tilde{i} \delta o \varsigma$. Based on the presence of such wording, it is possible to paint a big picture of the characteristics of the genre in ancient times: (1) it is mainly narrative, $\delta \iota \eta \gamma \gamma \sigma \iota \varsigma$-based $(\mu \tilde{v} \theta o \varsigma)$; (2) consists of a linear sequence which is comprised of meaningful syntactic elements ( $\sigma \hat{v} \gamma \gamma \rho \alpha \mu \mu \alpha)$; and (3) provides an image ( $\varepsilon \tilde{i} \delta o \varsigma)$, usually introduced by means of a description ( $\left.\varepsilon^{\prime} \kappa \varphi \rho \alpha \sigma \iota \varsigma\right)$.

\subsection{PAPyRACEOUS MATERIAlS}

In the face of data shortage, scholars have been prompted to explore alternative paths. A potentially enlightening alternative consists of conducting comparative analysis, in terms of numbers and materials of papyraceous novelistic pieces, in 
comparison with well-consolidated genres (Bowie 1996, Hunter 2008, Morgan 1995). Relatively speaking, few novelistic papyri have been preserved. Beyond reasonable doubt, the process of crafting and distributing the copies might have been too expensive to be affordable to a middle-class readership. Also, in terms of physical qualities and scriptural care, no salient differences are not found between the pre-Sophistic and Sophistic fragments. This may be used as evidence that the readership of novels was not subject to substantial change across both periods. Based on the preserved papyri, we find no evidence of the existence of a "low-cost" literary tier, aimed at entertaining poorly educated individuals.

All in all, it is essential to consider papyrological transmission as inevitably subject to the ups and downs of history. Concerning the Sophistic novels, in Oxyrhynchus and other locations throughout Egypt as many as six papyri have been preserved of Achilles Tatius (e.g., Leucippe and Clitophon), as opposed to only one of Heliodor (i.e., Aethiopica, also known as Teagenes and Chariclea) and none of Longus (who wrote Daphnis and Chloe). Such geographical precedence of Achilles Tatius may be accounted for either based on his Alexandrian origin (as shown in the Souda) or considering the fact that Egypt provides the central location of the author's plots.

\subsection{HERITAGE OF THE NOVELISTIC GENRE. INFLUENCE AND SUBSEQUENT TRADITION}

The role of novels in Antiquity can also be approached based on their influence and subsequent tradition. It may be enlightening to identify the periods of Ancient Greece during which the novelistic genre has enjoyed widespread prominence and historical continuity in the arts. ${ }^{5}$ As previously mentioned, Achilles Tatius was regarded as one of the top novelists in the area of Egypt. This might be simply due to the Egyptian color of the author's works, rather than a higher quality in comparison with other novelists such as Heliodor. ${ }^{6}$ In fact, it is Heliodor (for whom no readership is documented in Egypt until the 6th century) the first to report the existence of Achilles Tatius by outlining a brief biography of the author. According to this, Tatius would eventually have become the bishop of Tricca, Thessaly. ${ }^{7}$ Despite an apparent prominence of Achilles Tatius, his

${ }^{5}$ While artistic continuity might not be sufficiently revealing in terms of genre status, it might still confirm the quality of Greek novels on both the technical and stylistic levels.

6 Contingent on qualitative criteria, this might explain the success of Achilles Tatius in providing a key to the potential readership of Greek novels. Firstly, should Leucippe and Clitophon have stylistic and technical qualities greater setting it apart from other works, its readers might have pertained to a highly educated, refined elite. The precedence of this novel might also be explained in terms of readability or accessibility to the average reader, who would then fit well with the "intended reader" stereotype.

7 The biography of all Greek novelists (oftentimes including even their real names) remains largely unknown to date. Chariton, for instance, constitutes a doubly emphatic nom de plume, since it serves as an introduction to the work itself. The word can be traced back to the root of $\chi \alpha \dot{\rho} \rho \iota$ 
influence remains limited to a single text, the poem Hero and Leander by Musaeus, a Byzantine poet and $\gamma \rho \alpha \mu \mu \alpha \tau \iota \kappa o ́ s$. This may be providing additional evidence that novels were likely not a popular, "mass" genre in Antiquity.

Early novels (especially Chariton and Xenophon) would enjoy widespread dissemination in the Roman setting, as evidenced by Ovid's own account of the legend of Pyramus and Thisbe (Met. IV 55-166). Some scholars have pointed at the Metamorphoses as a parody of the New Comedy, while Holzberg (1995) claims that the work is, in fact, a parody of ideal novels. In a verse by Persius (I 134), a reference is found to the lead heroine in Chariton's novel: "post prandia Callirhoen do" ('[to these,] after lunch, I give Callirhoe as a present'). Petronius' work has oftentimes been cited as a burlesque parody of the ideal romance. Last but not least, it is important to consider iconographic evidence from the Severan dynasty -more specifically, a couple of mosaics from an Antioch home which portray Metiochus and Parthenope (who appear identified by their own names), as well as one mosaic depicting Ninus. It would appear that the owner of the house could have known of the existence of these characters, not through immediate reading, but rather thanks to some sort of theatrical performance (mimes?). ${ }^{8}$

\section{THE DEBATE ON GENRE HOMOGENEITY. MULTIPLE READERSHIPS?}

Before an ideal readership may be outlined, it may be relevant to explore outstanding evidence in order to determine the degree of homogeneity of the genre. Should novels turn out to be highly heterogenous, this might cause the concept of genre itself to wobble and, relatedly, it would make it necessary to establish different readerships for the same genre. I will approach this issue by exploring the aspects which appear to be common to all novels. This will allow me to establish a highly applicable, multi-criterion definition of the genre.

\subsection{Conceptualizing the novel}

Novels pertain to a prosaic genre based on a diegetic sequence of actions, which are in turn expressed by means of a series of meaningfully sorted syntactic elements. This definition does not exclude alternative forms of elocution within

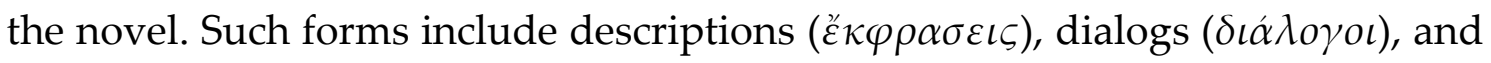
multiple rhetorical resources from $\pi \rho \sigma \gamma v \mu v \alpha \alpha \mu \alpha \tau \alpha$ (2nd and 3rd centuries), which encompass the $\mu \tilde{v} \theta o \varsigma$ ('account'), $\chi \rho \varepsilon i \alpha$ (practice-oriented ethical maxim),

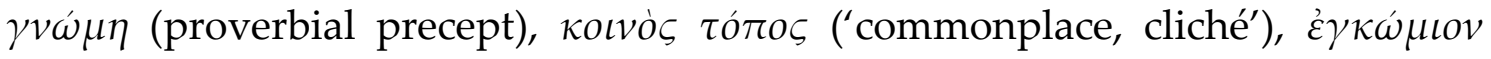

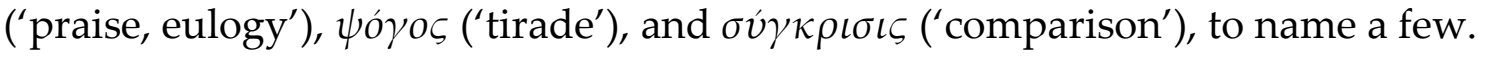

('grace'), which underscores the idea of sensitivity and sensuality associated with ع́ $\rho \circ \varsigma$ ('love'). On the other hand, Aphrodisias is a city dedicated to Aphrodite, goddess of love.

${ }^{8}$ Lucian usually refers to Ninus and Metiochus as characters of a theatrical performance. 
Another characteristic shared by most novels lies in their parodic content. On the other hand, both the geographical and the chronological scopes of novels appear to be well-defined. Firstly, the birthplace of the genre is traditionally identified with the eastern Asia Minor and western Aegean regions. Secondly, ancient Greek novels stretch over a period ranging from the 2 nd to the 4 th centuries, in the times of the Roman Empire. ${ }^{9}$

There are a number of distinguishable elements of novels which set these apart from preceding literary products. First and foremost, the new genre is no longer at the service of the pólis, but instead caters to the recipient's enjoyment, learning, and potential reflections. Far from the camaraderie found in the Iliad's hoplite phalanx - and also at a great distance from theatrical reflections on human relationships - novels portrait individuals who eventually find themselves on their own as they face impeding perils in their quest for a much longed-for love. In a new godless, individual-centered world, random fate becomes ever-present. In novels, time creates a structure of non-self-sufficient chapters which are limited in number. This may lead us to consider the precedence of writing over an oral medium. Originally, orality might have determined the coexistence of multiple versions of the same account, as well as an as-needed addition or suppression of episodes and the resort to in-verse, formulaic language for mnemotechnic purposes. In contrast, novels show a text which has remained fixed from the beginning. With verse no longer being a requirement, the diegesis of a linear sequence of events becomes one of the most salient features of the genre.

Another key component is fiction. Regarding prior literature, it is still possible to assume the mythification of a remote and sometimes superhuman reality. In novels, fiction becomes a shared code between the author and the reader. Despite multiple instances of idealization, novels strive to limit

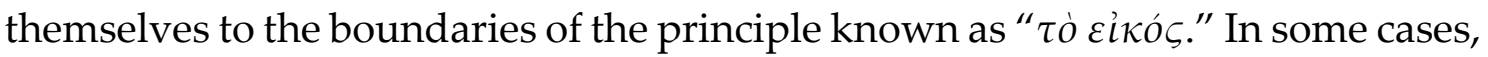
the plot is even self-described as "real" in an attempt of self-legitimation, which goes hand in hand with the compensatory function typical of novels. This potentially suggests an educated reader, one that would have been able to interpret novels as fictitious works which are inspired by the literary-game tradition started by Hellenistic poets (e.g., Callimachus, Theocritus, Apollonius of Rhodes). In Chariton, subtle references abound to the blurry line that sets apart reality from fiction:

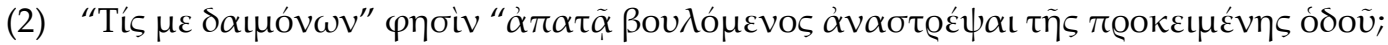

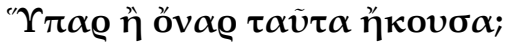

\footnotetext{
9 Exact dating of specific authors involves great difficulty. Based on formal complexities, Sophistic novels appear to be more elaborate than pre-Sophistic ones. Oftentimes, this has been interpreted as an indicator that the former mark the heyday of the genre.
} 
'Which god -he said-is deceiving me, urging me to return from my predestined path? Those things I've been able to listen to-are those reality or a dream?' (Char. III 14 )

Another shared trait is found in commonplace motives which are already usual in Chariton, such as youth and beauty, love and jealousy, search and reunion, apparent death, pirates, slavery, and erotic rivalry. Although these leitmotivs are subject to some variatio in some novels, they provide a unifying thread within the account, adding to the evidence of a homogeneous genre. To this respect, it may be important to remember that novels, as products of a new period, are the carriers of a new spirit (see Section 1).

\subsection{Typological systematization of the novelistic genre. Conclusions}

Multiple scholarly attempts have been made to establish a concise, agreed-upon classification of the genre. However, diverse criteria call for simultaneously embracing multiple, non-mutually-exclusive classifications. Based on this, it is not preposterous to question whether the novel label might have been used to refer to a multiplicity of interrelated genres.

\subsection{1. "Ideal" vs. "other" novels}

The current corpus of novels may be scarce when compared to the materials which may once have existed. Due to this, scholars tend to face a number of restrictions and shortcomings as they analyze the genre as a whole. A large majority of research is based on books which are preserved in their entirety (cf. "ideal" novels). Still, we have access to fragmentary pieces, such as Lollianus'

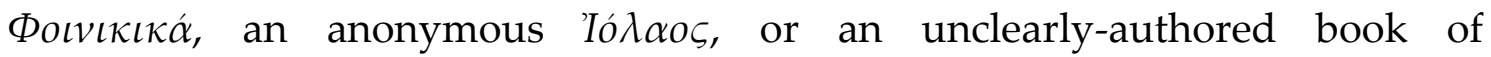
Metamorphoses. ${ }^{10}$

Even as we focus on the canonical corpus, we have no solid evidence that Chariton would have been the pioneer, although he is broadly known to be one of the earliest novelists (West 2003). More often than not, neither authors nor their works can be dated easily. Nowadays, many scholars consider a twofold classification of the corpus of novels. An early differentiation opposes the "canonical" novels to those preserved fragmentarily, which have left behind the

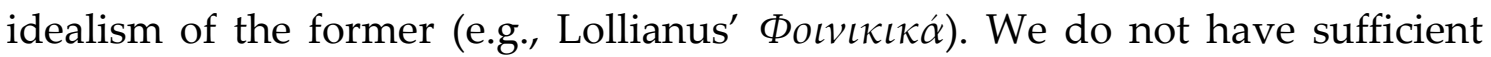
evidence to conclude that these novels were qualitatively inferior to the ideal ones. Stylistic differences are encountered across novel types, with ideal novels being characterized by their Atticism, hiatus, and tendency to employ sentences and morality. In ideal novels, parallel or common motives are found across works, based on which the existence of intrageneric intertextuality might be

\footnotetext{
10 Traditionally, the authorship of this book of Metamorphoses has been attributed to either Lucian or - according to Photios- Lucius of Patra.
} 
assumable. An example is provided by the heroines in Xenophon and Heliodor, respectively Anthia and Chariclea, both of whom take on the role of Artemis. ${ }^{11}$

Literary analysis of the genre and its socio-cultural contexts has traditionally been approached from the perspective of the ideal novels, which are quantitatively rich in materials. While my analysis will also focus on this group of novels, still a potential discovery of more "apocryphal" novels might become a game changer at any point.

\subsection{2. "Early" vs. "Sophistic" novels}

Within the group of ideal novels, a distinction is often established between early, pre-Sophistic novels and Sophistic novels. Comparatively unassuming, the former come earlier in the timeline and evince an embryonic development of the genre. While they may not have lower stylistic qualities or be addressed to a broader readership, readability in these novels tends to be higher than in those from the subsequent period.

Among the pre-Sophistic novels, those entirely preserved are Chaereas and Callirhoe, by Chariton of Aphrodisias, and the Ephesian Tale of Anthia and Habrocomes, by Xenophon of Ephesus. The earliest evidence of ideal novels (e.g., Ninus and Semiramis, Metiochus and Parthenope, Chione), yet fragmentary and undated, can also be included here. In his comparative analysis of Chaereas and Callirhoe, on the one hand, and Metiochus and Parthenope and Chione, on the other hand, Holzberg (1995), based on the language and certain motives, concludes that the two latter works might also be attributed to Chariton. Finally, the epistolary novel Letters by Chion of Heraclea is usually dated back alternatively to the late first century or the fourth century $\mathrm{AD}$ - should the former hold true, it could be included in this group of novels.

Sophistic novels, which come in at a later date, appear to be more complex from a literary standpoint. In them, a determination to emulate is clearly detected. While the new authors do not reject pre-Sophistic novels, yet they take those as mimetic starting points in their quest to "perfect" the genre. Sophistic works include Leucippe and Clitophon, by Achilles Tatius; Daphnis and Chloe, by Longus; and Theagenes and Chqriclea (also known as Aethiopica), by Heliodor. As for Achilles Tatius, we have emphasized that he was the preferred author in the area (see Section 2.2). However, the remaining two authors have been regarded as equally sophisticated, with Heliodor frequently being credited for leading the genre to its heyday. Though acknowledging the complexity of Heliodor's work,

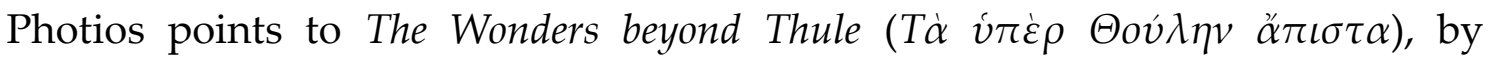
Antonius Diogenes, as an even more complex work.

\footnotetext{
${ }^{11}$ Heliodor might be emulating Xenophon here, as he takes the character to the next level (literary speaking).
} 
Most current scholars conclude that it is feasible to envisage a homogeneous genre. In the following section, I will be particularly careful in delving into the potential readership of novels, contingent on the type of work under analysis.

\section{THE READERSHIP OF EARLY NOVELS. WOMEN AS POTENTIAL READERS}

\section{1. "Intended readership" and "actual readership" (Bowie 1996)}

Based on the above, it may be concluded that the potential readership of novels might have been essentially the same for all types. In words of Bowie (1996), works from both periods would have the same "intended readership," but differ in terms of their "actual readership." However, even with regard to the intended readership, Bowie emphasizes the existence of a variety of readers. Other scholars have proposed that novelists would not have targeted a specific readership, but rather this would have been the by-product of formal and accessrelated constraints. For these scholars, only the study of "actual readership" would be appropriate or feasible, even if it is usually more difficult to establish than intended readership.

Faced with scarce data on the de facto readership, the only possible approach appears to lie in the study of the intended readership. According to Hägg (1994), Bowie's division is ideal, not feasible based on the low number and quality of preserved papyri. I will here focus on pre-Sophistic novels, which are most controversial in addressing their potential audience(s). As for Sophistic novels, it seems assumable that complex pieces (e.g., Heliodor) may have originally been addressed to a select group of readers, who would have been well-versed in the literary and cultural underpinnings of Ancient Greece.

\subsection{Literacy in the time of novels: A state of the issue}

As found for the Hellenistic and Imperial periods, an increase in literacy often goes hand in hand with practical purposes, such as fostering trade. Along these lines, no evidence is found of higher reading rates for literary pieces such as novels, which still appear to target certain elites.

Like reading, writing was probably widespread within such elites. However, it was certainly not considered a banal or otherwise minor activity, but rather one requiring focus and funds. In novels themselves, especially in Xenophon, we can find some clues regarding said "high-end" role of writing:

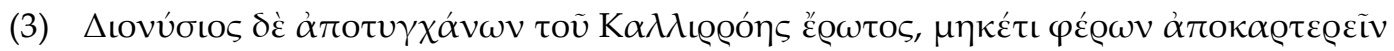

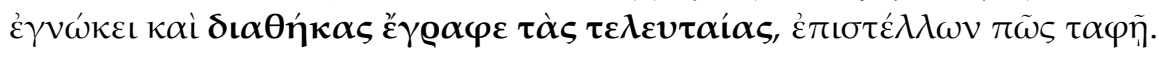

'Being unable to conquer Callirhoe's love and also unable to cope with this situation for longer, Dionysus had decided to starve himself to death, and had started to write his last will, emphasizing how he wanted to be buried.' (Char. III 1 1. A strictly extraliterary use of writing is hereby shown.) 


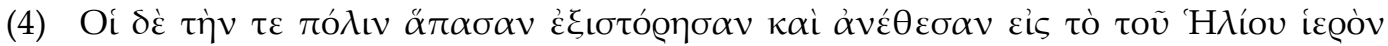

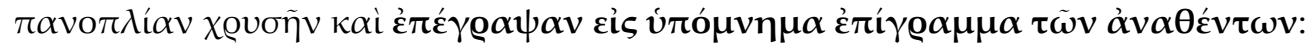

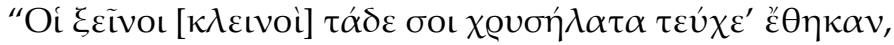

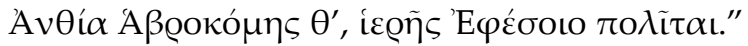

'They [i.e., Habrocomes and Anthia] visited the entire city [i.e., Rhodes] and dedicated a golden armor before the temple of Helios. So that everyone could remember the dedicators, they engraved the following: «Some foreigners have offered you these golden weapons; Anthia and Habrocomes, citizens of the sacred Ephesus.»' (X. Eph. I 12 2. Religion was yet another field in which writing would become necessary, especially in the form of inscriptions.)

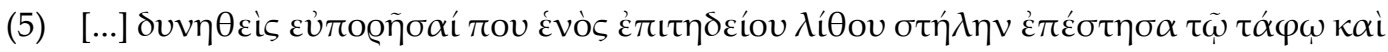

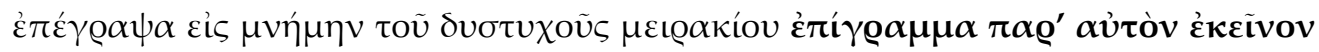

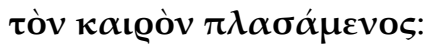

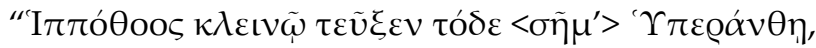

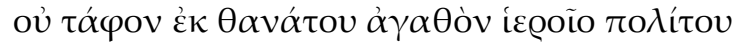

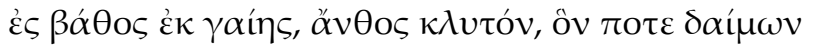

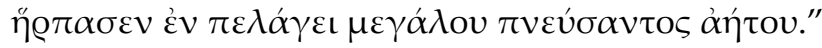

'[...] I was able to find a stone like the one I needed and placed a stela standing on the grave. It was exactly then that, in the memory of the unfortunate teenager, I myself wrote an inscription that went: «Hippotous built this grave for the nobleman Hyperanthes. It is not the grave deserved by such an important citizen, who already lies under earth; he, the magnificent flower which a god gave for dead offshore, as a result of a strong windstorm».' (X. Eph. III 2 13. In connection with the previous fragment, funerary inscriptions, like the one Hippotous dedicates to Hyperanthes in Lesbos, provided another context in which writing was often resorted to.)

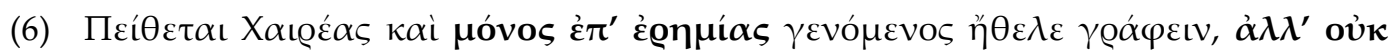

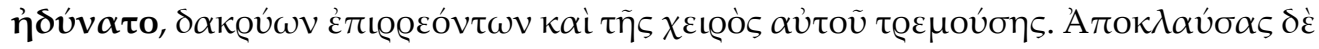

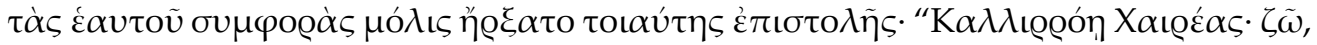

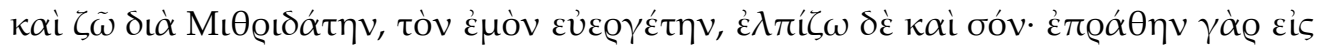

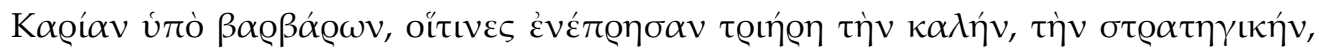

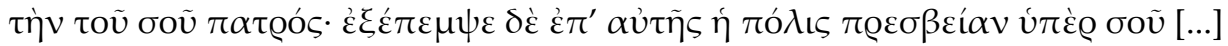

'Chaereas convinced himself and, on his own, in a quiet place, he wanted to write, yet he could not make it, as he was in tears and his hand was shaking. He mourned his misfortunes as he was barely able to begin the letter: «Chaereas to Callirhoe. I am alive, and this is thanks to Mithridates, who is my benefactor and I hope is yours, too. I was sold to Caria by the barbarians, who set the trireme on fire, the beautiful one, the admiral, your father's. On board of it, the city had sent an embassy to retrieve you [...]»' (Char. IV 4 6-10. This passage demonstrates that letter writing, even for the highly literate, demanded great mental focus.)

In the next section, I will approach the issue of the role of women as novel readers. Regarding pre-Sophistic novels, no evidence is found that female literacy rates would have been inferior to their male counterparts. An instance of this can be seen in Xenophon, specifically in the fluent correspondence between Manton and Habrocomes, ${ }^{12}$ and also in the offering which Habrocomes and Anthia deposit in Rhodes to honor Helios (see above). In spite of these and

\footnotetext{
${ }^{12}$ An example of this is found in the subsequent section.
} 
similar examples, widespread literacy in women should not be assumed as a result. From an idealist perspective, novels target an elite audience, based on which they serve a twofold compensational and identifying purpose. Even as there must have been literate women in such societal layers, these were probably not too numerous. In contrast, Xenophon tends to depict this reality as commonplace. ${ }^{13}$ Another case in point is found in the passage where Anthia devotes her hair to the god Helios, which she records through an inscription (V $116)$ :

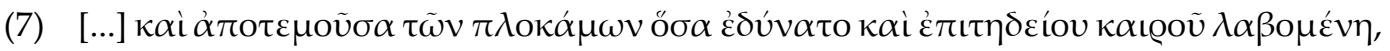

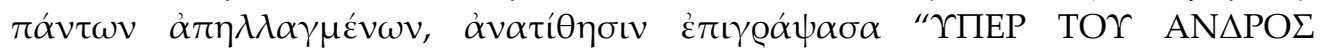

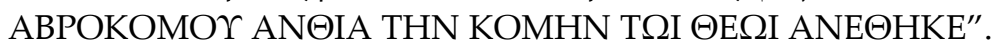

'[...] she cuts her hair as short as she possibly can, as she awaits the right time, once everyone has left the temple, to engrave the following inscription: «IN ORDER TO HONOR HER SPOUSE HABROCOMES, ANTHIA HAS DEVOTED HER HAIR TO THE GOD».'

\subsection{Literary techniques and reader-types. Could the precedence of women provide evidence for an essentially feminine audience?}

In pre-Sophistic novels, no conclusive evidence is found to support neither widespread literacy during the Hellenistic and Imperial periods, nor mass dissemination of the novelistic genre. ${ }^{14}$ As earlier mentioned, increases in literacy were probably associated (at least originally) with the pursuit of non-literary purposes. In all likelihood, widespread novel reading is not presumable with elementary literacy rates. Additionally, no evidence is found for an increase in leisure at the time (West 2003).

Although books had become increasingly accessible, they were still regarded as precious items. This nature of the book as something exceptional is documented in the passage by Achilles Tatius which serves as a heading in Bowie (1996):

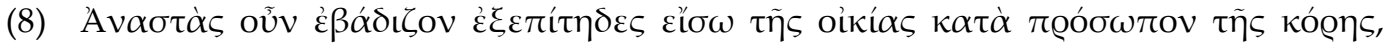

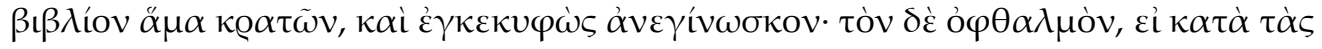

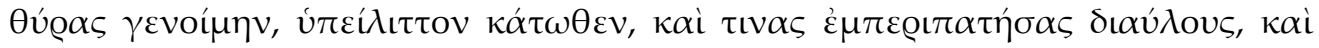

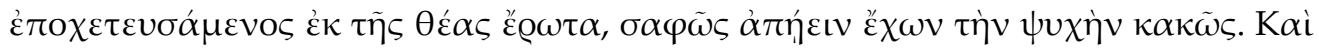

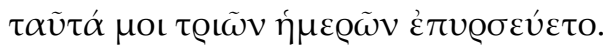

'I then got up and deliberately walked around the inside of the house, in plain sight of the girl, as I took a book in my hands, looked toward it, and read it. Yet, whenever I was by the door, I looked downward. After going back, filled with love by the

\footnotetext{
${ }^{13}$ This is most likely due to the idealism intrinsic to the author's literary production.

${ }^{14}$ The entire manufacturing and transportation process of a book would have entailed huge expenses. Additionally, novel readers would likely not be able to do this at a faster pace than reading out loud, which was still the most common practice at the time (Knox 1968).
} 
goddess, I left with a heavy heart. That flame kept burning inside me for three entire days.' (Ach. Tat. I 6 6)

The above is probably the only metaliterary reference concerning the dissemination of novels (provided that we consider the book being read by Clitophon to be a novel). Based on this, readers of novels must have been, not only elite, but also refined, with a deep knowledge and taste for Greek literature. Bowie (1996) claims that the readership of novels would have corresponded to the very same societal elites that used to read authors such as Plutarch, even though reading would have served different purposes. Thanks to their literary awareness, readers would have shown high degrees of versatility in their own access to and use(s) of literature.

Earliest novels are different from Sophistic ones in the fact that they tend to be more sentimental and resort to less complex narrative techniques. Initially, this led scholars to believe that the genre had emerged as a minor genre (cf. Philostr. Epist. 66; 2.1.). It is not a new readership, but rather a new genre that emerged, one which targets a select group from a prior readership (Hägg 1994). According to Hägg (1994) and West (2003), most misconceptions regarding the issue under study are likely due to modern analogies.

Plepelits (1976) mentions that the status of women in society had improved considerably in Hellenistic times. Still, men continued to be the first and paramount recipients of literacy. At this point, the hypothesis that women were the main recipients of novels no longer appears to hold true - at that time, not many women might have been able to fully comprehend complex intertextual allusions, which abound in authors like Chariton. Bowie (1996) also supports this viewpoint, even if novels usually depict a heroine who plays the lead as opposed to her lover. Regarding both the prosopography and psychological $\dot{\varepsilon} \kappa \varphi \rho \alpha \dot{\alpha \varepsilon \varepsilon \iota \varsigma}$ of the heroine, there is a constant focus on her $\kappa \dot{\alpha} \lambda \lambda \varsigma_{\varsigma}$ ('beauty') and $\sigma \omega \varphi \rho o \sigma \dot{v} v \eta$ ('sensibility'), loyalty, and providence. Here are some relevant passages found in Chariton's piece, as applied to Callirhoe:

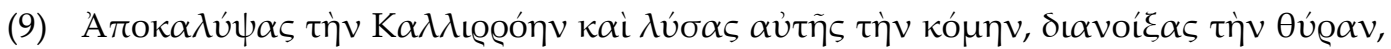

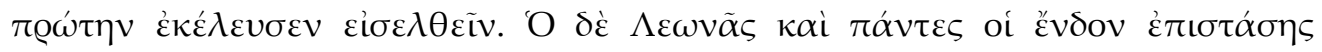

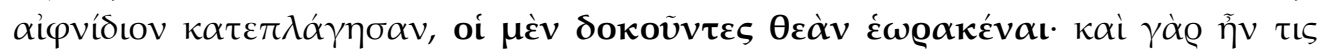

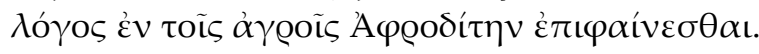

'He found Callirhoe and rinsed her hair, opened the door, and asked her to come in first. Leonas and everyone inside were astonished as she showed up. Some believed they were seeing a goddess. Rumor had it that Aphrodite herself used to appear among those fields.' (Char. I 14 1)

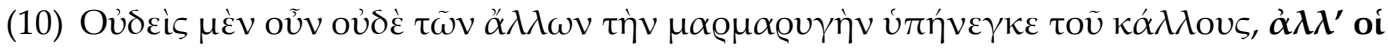

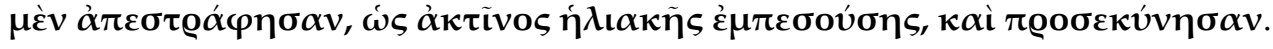

'In fact, no one could resist her sparkling beauty. On the contrary, they turned their faces, as if a sunbeam had fallen, and leaned forward to adore her.' (Char. IV 19$)$

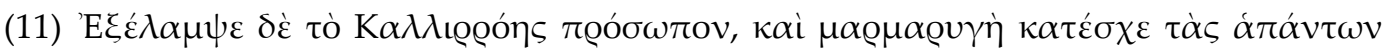

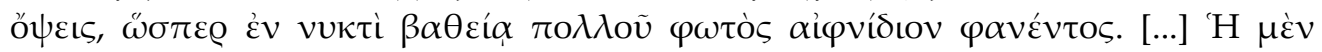




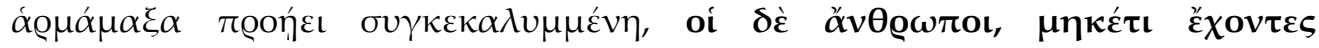

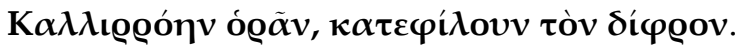

'Callirhoe's face shone as the sparkling took over everyone's glances, like when a light suddenly shows up at night. [...] The covered carriage was moving forward as the people, who were unable to see Callirhoe, would kiss the cart.' (Char. V 3 9-10)

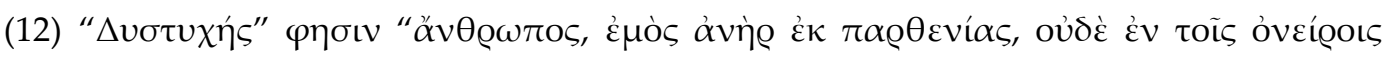

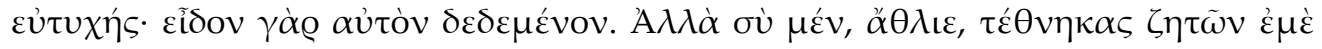

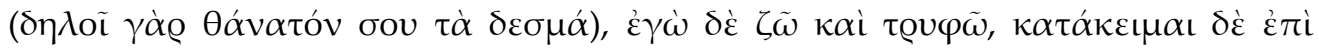

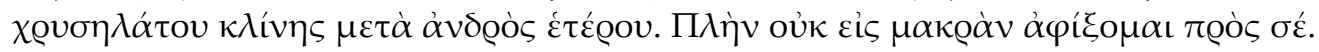

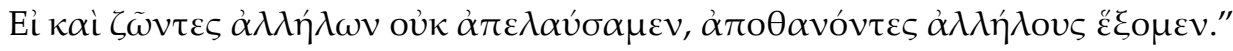

'The spouse I had in my youth is an unfortunate man -he said. He is not even fortunate in my dreams-I saw him chained. You, unfortunate, died as you searched for me (since your chains are a symbol for death), while I am alive and live luxuriously as I lie with another man on a rolled-gold bed. Yet, I will shortly be where you are. If we did not enjoy each other in life, we will have each other in death.' (Char. III 7 5-6, which illustrates Callirhoe's providence)

Novels present a kind of sentimentalism and psychological reflection which, in the collective imagination of Greeks, would be especially associated with the feminine figure. The role of women as lead characters in novels appears to be beyond question. ${ }^{15}$ Multiple scholars (Bowie 1996, West 2003, Hunter 2008) seem to agree that the concern about the $\pi \dot{\alpha} \theta o \varsigma \dot{\varepsilon} \rho \omega \tau \iota \kappa o ́ v$, typically associated with women, is in fact related to the "compensatory role," as mentioned by Morgan (1995). According to this, novels would always remain within the limits of verisimilitude as they would simultaneously provide their male readership (i.e., Greek, upper-class, educated, sentimental) with a chance to escape from their uncertain, individualistic reality. To this end, a fanciful romance was recreated in which the woman appears to be an object of desire to such male readership (Hunter 2008). However, this does not exclude the possibility of women being part of the "actual readership." Mentions on this are scarce and ambiguous. Photios mentions that Diogenes had written a preface to Td $\dot{v} \pi \dot{\varepsilon} \rho$ $\Theta o v i \eta v \ddot{\alpha} \pi \iota \sigma \tau \alpha$ in which he dedicated his work to his sister Isidora (Phot. Bibl. 166 111a30). However, this dedication was part of a larger letter to Faustinus, who probably was Isidora's spouse. Based on this, novels likely targeted an "intended readership" comprised of a number of $\pi \varepsilon \pi \alpha \iota \delta \varepsilon v \mu \varepsilon v v \iota$ who were wellversed in Greek literature and, thus, potentially able to comprehend subtle intertextual references in an apparently effortless manner.

Being the least formally complex, early novels are often the most controversial. I will follow the common scholarly practice of taking Chariton as a starting point, as I leave aside the controversy surrounding Xenophon of Ephesus. Here are some instances of intertextuality that are found in Chariton's work, many of which can be traced as far back as the Homeric poems:

\footnotetext{
15 Originally, it was common for the novels to receive the title of their main heroines (e.g., Callirhoe, Anthia).
} 


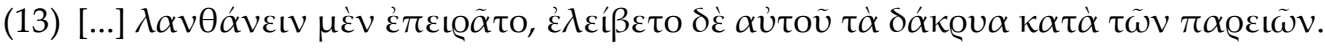

'[...] due to all his efforts to go unnoticed, tears were slipping down his cheeks.' [Char.

524 (cf. Xen. Cyr. 6.4.3)]

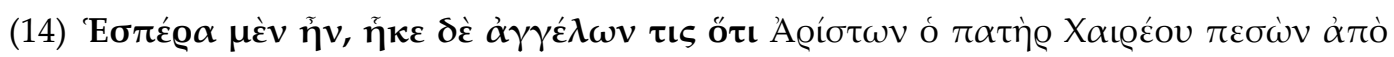

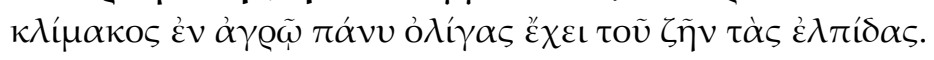

'It was the evening, and someone came to carry the news that Ariston, Chaereas' father, had fallen from a ladder in the field, and hopes for his life were scarce.' [Char. 131 (cf. Dem. De cor. 169)]

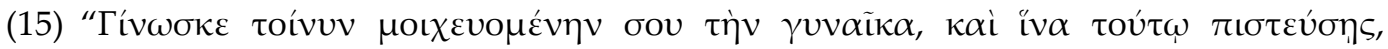

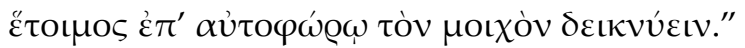

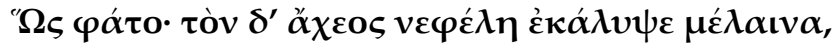

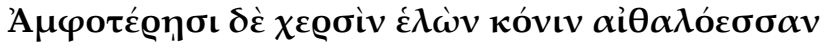

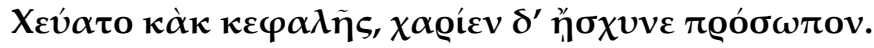

'«Know, thus, that your wife lets herself be seduced, and, so you believe this, I am willing to show you the adulteress red-handed».

So he spoke. A dark painful cloud surrounded him, with both hands taking the charred ashes he poured those as his face became contorted. [Char. I 46 (cf. Il. XVIII 22-24)]

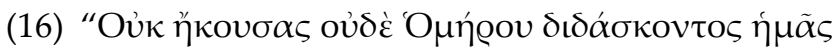

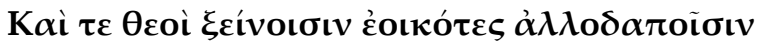

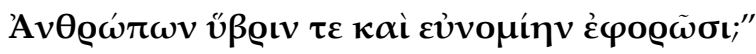

'«You have not even heard Homer, who teaches us:

And do the gods, similarly to foreigners from other countries,

observe the insolence and the sense of justice of mankind?» [Char. II 37 (cf. Od. XVII 485-487)]

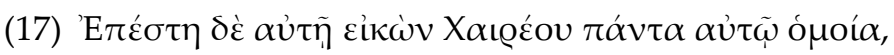

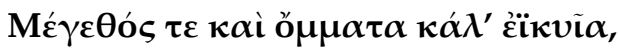

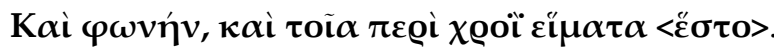

The image of Chaereas would appear before him, entirely resembling himself,

resembling himself for his greatness and his fair eyes,

and for his voice, and for the outfit he used to wear over his body. [Char. II 96 (cf. Il. XXIII 66-67)]

This kind of intertextual references (which sometimes are actual quotes) are commonplace throughout the work of Chariton. Chaereas and Callirhoe is the preSophistic work closest to those from the next generation. Unlike Sophistic novels, however, references in this novel tend to be transparent, not compromising overall readability. These usually consist of similes between Callirhoe and a number of Homeric characters. There are also gnomic, universal sentences which may apply to any given period or society in history.

The understanding of less explicit allusions does not appear to pose a sine qua non when it comes to effectively reading the words of Chariton. Based on intertextual analysis, multiple authors (Bowie 1996, West 2003, Hägg 1994) agree on pointing at a two-level reading of Chariton - a two-tier hermeneutic interpretation. Other scholars (Morgan 1995) do not explicitly refer to this, yet they tend to outline the stereotype of a versatile readership. Following Bowie 
(1996), an exact correspondence is not found between intended and actual readership. Novel appears to admit certain flexibility in terms of readership, even within the aforementioned elites.

Xenophon's Ephesian Tale has oftentimes been referred to as an example of an assumed inferiority of novels in comparison with the other genres. With this idea being outdated, modern scholars tend to search for more plausible explanations. Indeed, Xenophon's work distances itself from previous novels to various respects. Firstly, not many intertextual references are found therein. Secondly, dialogs are also remarkably scarce, while other novels resort to them systematically in their search for a dramatic, sentimental atmosphere. This might also explain how little characters appear to participate in the plot. Thirdly, Chariton's mastery of the narrative techniques contrasts with Xenophon's preference for syntactic successions of paratactic, quasi-telegraphic components. Fourthly, no recurring, consistent use of $\dot{\kappa} \kappa \varphi \rho \alpha ́ \alpha \varepsilon \iota \varsigma$ is found in Xenophon, as opposed to Chaereas and Callirhoe. A potential explanation for this may be that Xenophon's piece might simply correspond to a $\pi \rho o ́ \gamma \rho \alpha \mu \mu \alpha$, an embryonic draft of a novel which would never have been released in full (Bowie 1996).

Hägg (1994) claims that the key might be found in non-preserved novels. While this is still a possibility, it is also difficult to determine. Bowie (1996), who at this point appears to provide the most plausible explanation, bases this assumption on the multiplicity of epistle-like materials in Xenophon's work. The author also underscores the contrast across materials in terms of stylistic qualities, as well as the $\delta \iota \eta \gamma \eta \mu \alpha$ in which those materials were eventually inserted. A self-explanatory example is found in Manton's ${ }^{16}$ letter to Habrocomes:

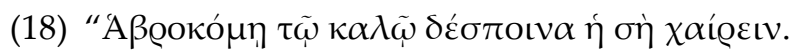

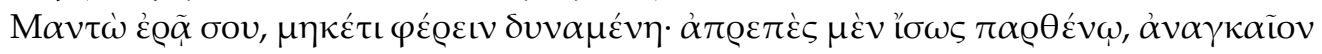

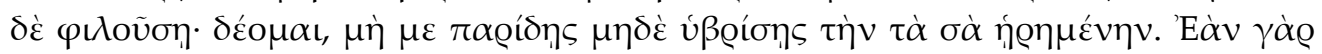

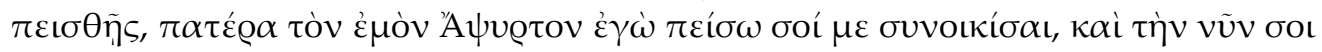

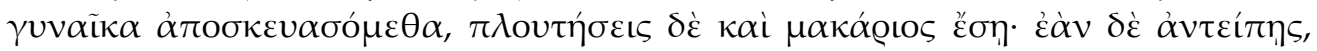

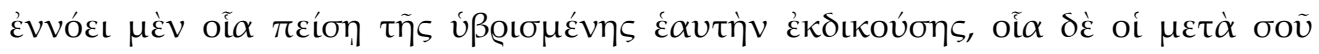

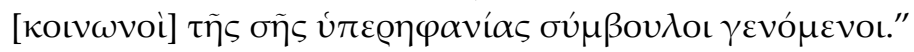

" «To handsome Habrocomes, his mistress wishes him good health.

Manton loves you, yet she cannot stand it. It is not decent for a maiden to confess this, yet she is forced to do so by love. I beg you -please do not despise me or be arrogant about someone like me, who loves everything related to you. If you follow my advice, I will convince Apsyrtus, my father, so he will allow me to marry you. We will get rid of your current wife, so you will be wealthy and happy. However, if you oppose, you should start to think about what might happen to you. I will be indignant and know how to conduct my revenge. Also, picture what might happen to your colleagues, who were accomplices of your scorn».' (X. Eph. II 5 1-2)

\footnotetext{
${ }^{16}$ Manton is the daughter of Apsyrtus, who is in turn the leader of the pirate band.
} 
In early versions of the piece, letters would take the back seat, as though they had been composed separately from the main work. One possibility is, thus, that, while the letters might be found in their final version, the account in which they are inserted might be a mere draft of the plot which was due for further ampliatio later on. Such expansion might have been made possible by adding stylistic resources which would allow for a literary game. In the context of novels, highly-stereotypical plots are likely to provide the perfect pretext to deploy a complex literary game. ${ }^{17}$ In order to please the average readership, any given novel might have required to meet some basic standards in terms of stylistic qualities. Along these lines, the plot of the Ephesian Tale, which is almost completely diegesis-based, might have already been known at the time to readers of novels.

\section{READERSHIP OR LISTENERSHIP?}

\subsection{General considerations on orality}

So far, I have approached the issue under study on the grounds that the Ancient Greek addressees of novels were actual readers. I have also pointed that literacy rates were never too high, and these were rather restricted to the elites, particularly the male population. No conclusive evidence is found in support of a mass circulation of papyrus. Based on this, orality might have provided the genre with a perfect means of dissemination. Initially, this would only appear to apply to pre-Sophistic novels. The formal complexity of Sophistic novels may be an indicator that these pieces were not intended to be recited before an auditorium, but those were rather conceived to be read on an individual basis - either out loud (a common practice at the time) or in a low voice (which would not have been as common, since it requires an outstanding degree of familiarity with reading).

Novels, which were initially conceived with a select target audience in mind, may have expanded its actual readership over time. West (2003) highlights the assumption that early novels might have enjoyed widespread dissemination among a mostly feminine audience within a textile context, to which many women used to dedicate their leisure. This sphere appears to be intrinsically linked with various types of narratives. Some instances of this are found in authors such as Vergil (G. IV 345-7) —who describes how Cyrene and her colleagues are mutually entertained by " $\varepsilon \rho \omega \tau \iota k \dot{\alpha} \tau \alpha \theta \eta \mu \alpha \tau \alpha$ " - and Ovid (Met. IV 31 et seq.) - who refers to the case of the daughters of Minyas. Therefore, early novels were likely conceived considering the possibility of oral dissemination. In

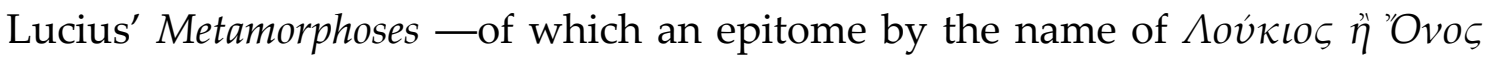

\footnotetext{
${ }^{17}$ Early novels still lack suspense, which will become a paramount feature of subsequent works, even though plots will remain based on similar motives.
} 
was released at some point - we find a potential attempt to make the novel accessible to alternative spheres.

From time immemorial, orality had been a means of expression for accounts of all sorts. In the absence of a generalized practice of writing, orality had developed a number of mechanisms, rendering it self-sufficient and efficient to fulfill said purpose. Such mechanisms encompassed the resort to formulaic language and alliteration. These are similarly found in the Homeric poems, where they originally assisted with memorization. Although almost everyone with basic education would most likely have been able to recite entire passages from the Iliad or the Odyssey, such recitation was also conducted professionally by rhapsodes. In novels, text support - even in the absence of widespread literacy- overcomes the reciter's need for full memorization, the use of verse, and - relatedly - formulaic phrases similar to those found in the Homeric poems. If we focus on Chariton and leave aside the controversy surrounding Xenophon, we can still find certain traits which appear to ensure the fit of the novel within a secondary, oral context. This, grosso modo, includes predictability, redundancy, and ending each chapter in a way that implicitly encourages the recipient to read on.

In an attempt to fill a gap in research, Hägg (1994) — cited to this respect by Bowie (1996) and West (2003) — presents his conclusions regarding orality in the times of the novel. ${ }^{18}$ Traditionally, some scholars have assumed that, beginning in the Hellenistic period, the coexistence of orality and writing would have given way to a so-called "book culture." Callimachus and other poets from the

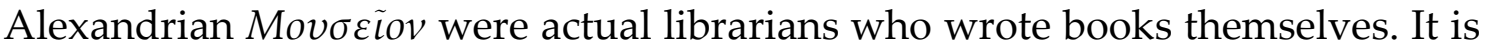
likely that pre-Sophistic novels would have initially been conceived to eventually be apt for oral dissemination. Following Hägg (1994) and — to a lesser extentother scholars, I will next focus on the analysis of select passages from Chariton of Aphrodisias and Xenophon.

\subsection{Analysis of passages from Chariton and Xenophon in connection with an oral medium of transmission}

Apparently, extensive evidence exists in support of an oral medium of dissemination for both Chaereas and Callirhoe and Habrocomes and Anthia. Hägg (1994) specifically distinguishes four pieces of evidence, which I will next itemize and illustrate accordingly. Such evidence is found in the presence of the following: (1) a high frequency of ' $\mu \dot{\varepsilon} v$ (...), $\delta \dot{\varepsilon}$ (...)' correlations; (2) detailed summaries or recaps; (3) proleptic materials; and (4) stereotyped phraseology.

Firstly, ' $\mu \dot{\varepsilon} v(\ldots), \delta \dot{\varepsilon}(\ldots)$ ' correlations appear frequently both in Chariton and Xenophon. In the latter, this might be an indicator that the work was at some point rendered suitable for potential oral dissemination. Hägg (1994) even holds

${ }^{18}$ The issue of orality has only been treated extensively as applied to the Archaic and Classical periods. 
the suspicion that Xenophon may initially have conceived his work for oral dissemination, while, at a later time, his novel may have been disseminated as a reading piece. An alternative explanation might simply be that the author, being heir to an essentially oral literary tradition, had those correlations deeply ingrained within his mind. Regardless, the audience of novels at this stage had most likely not fully transitioned to writing. Instead, echoes of orality were undoubtedly still present. Here are two examples, from Xenophon and Chariton respectively:

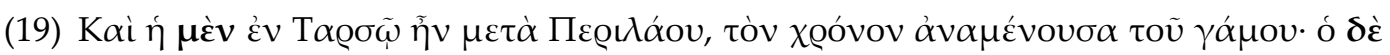

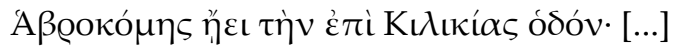

'She was then living in Tarsus, in the house of Perilaus, as she awaited the time for her wedding, and Habrocomes, on the other hand, was on his way to Cilicia [...]' (X. Eph. II 14 1)

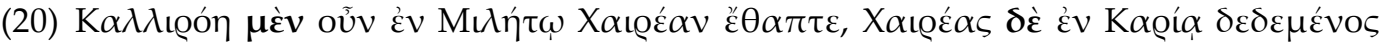

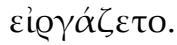

'So, Callirhoe was burying Chaereas in Miletus while Chaereas was working, chained, in Caria.' (Char. IV 2 1)

Regarding recaps, neither later, Sophistic novels nor any other prior work from Greek literature seem to effectively deploy such a systematic apparatus in terms of analepsis. This may well indicate that the passages involved actually fulfilled a distinct role. In Chariton, two recaps are found at the beginnings of the fifth and eighth books. Additionally, outstanding development of recap-related techniques can be seen, which would eventually reach their heyday largely thanks to Heliodor. In Heliodor's work, self-introduction of characters allows for covert analepses. Recaps like these constitute one of the paramount factors why scholars have identified an oral component in early novels. Length of these works would pose certain challenges for these to be fully narrated in a single sitting, for which segmentation would likely have been a must. Each part would be introduced by some brief passage, which, as a reminder, would seek to provide essential contextual clues. Hägg (1994) approaches this issue from a perspective of orality. In contrast, Bowie (1996) believes that the reason why recaps were used to head papyrus scrolls is that a whole literary piece would not have fitted in a single support - relatedly, access to all scrolls of a piece would have posed a myriad of challenges. While Hägg's (1994) proposal is certainly not to be dismissed, it is probably not essential to conclude that early novels had some sort of oral transmission attached. Here are some examples:

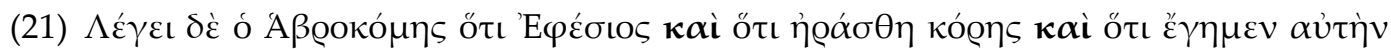

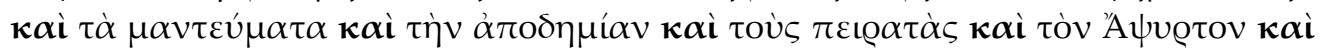

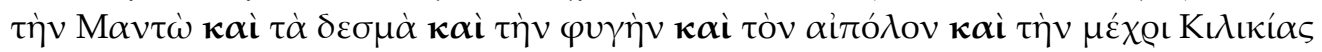
óónv.

'Habrocomes says that he is an Ephesian, and that he has fallen in love with a girl and married her; and he talks about the prophecies, and the trip, and the pirates, and 
Apsyrtus, and Manton, and the chains, and the escape, and the goatherd, and his journey to Cilicia.' (X. Eph. III 31 ; the $\kappa \alpha i$ polyptoton appears to point in the direction of orality.)

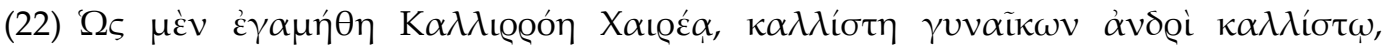

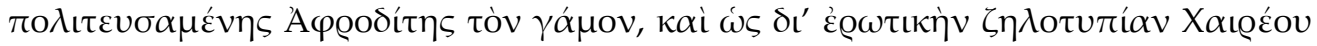

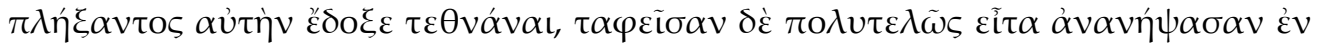

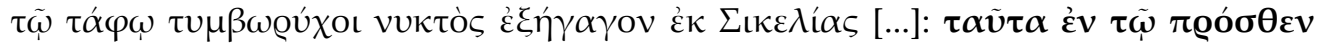

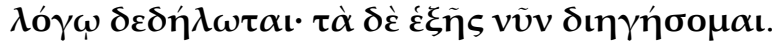

'How Callirhoe was taken as a wife by Chaereas, the most beautiful of women by the most handsome of men, with Aphrodite, who was directing the wedding, and how, after Chaereas hit her out of affectionate jealousy, it looked as though she had died, was buried with a lot of luxury and afterward she recovered at the tomb and some grave robbers took her out at night to Sicily [...]: these experiences have been presented in the preceding account; I will now tell the upcoming.' (Char. V 1 1-2; recap by the narrator which serves as a heading of the fifth book, with a final justification)

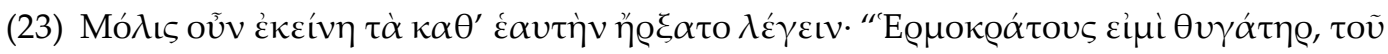

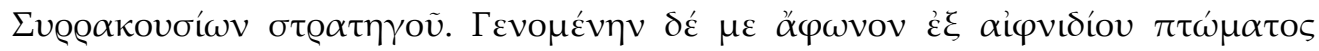

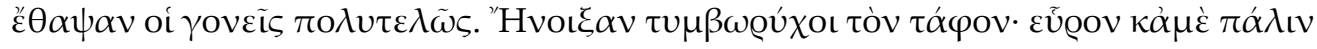

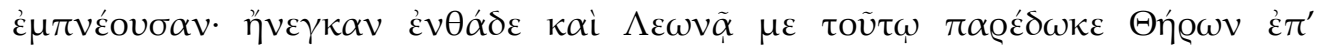

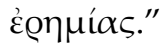

'She [Callirhoe], thus, little by little started to tell her stories: «I am the daughter of Hermocrates, the strategist of Syracuse. I lost my voice after a sudden fall, and my parents made me a sumptuous funeral. Some grave robbers opened my grave; there they also found me, who had started to breathe again; they brought me here, and, in a solitary place, Theron delivered me to this Leonas».' (Char. II 5 10; recap by Callirhoe through her self-introduction before Dionysus.)

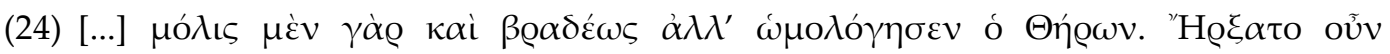

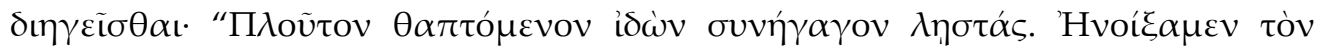

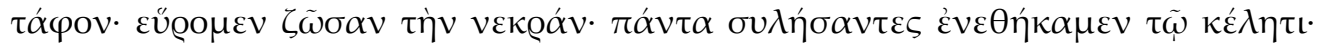

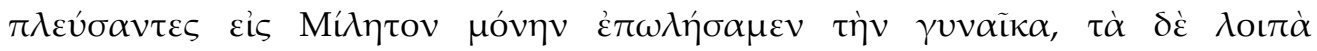

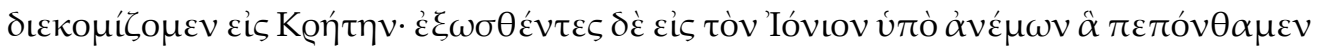

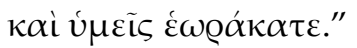

'[...] with great difficulty, little by little, Theron confessed. He then started to speak: «I had seen a buried treasure, so I gathered the thieves. We opened the grave, where we found the dead lady alive; we looted the whole place and loaded it all onto a ship; we set sail to Miletus, and we only sold the woman there; we took the rest to Crete. However, we were rushed to the Ionian waters by the wind, and you all have seen what we have been through next».' (Char. III 4 13-14; recap of an episode through the confessions made by Theron)

Proleptic materials - either anticipation or foreshadowing techniques - are also relevant as they might serve a similar goal to that of the recaps. This would consist of ensuring efficient oral transmission by resorting to a high number of references which would allow the audience to easily follow the plot thread. Proleptic passages are Chariton's choice when he needs to address his own audience, which he commonly does using a relaxed, friendly tone: 


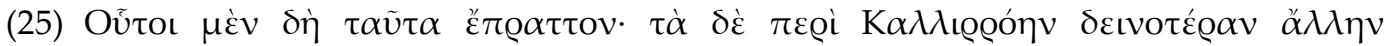

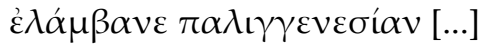

'This is what those guys [i.e., the thieves] did. As for Callirhoe, she came back to life! $[\ldots .$.$] ' (Char. I 81$ 1)

Last but not least, in Xenophon we find stereotypical phraseology typically linked with specific scenes, which in turn are equally stereotypical. For instance,

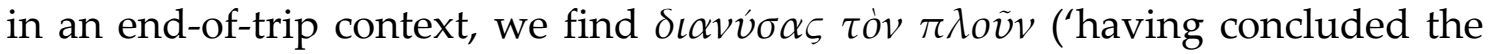
sailing'), ${ }^{19}$ whereas someone affected by "love sickness" is described as " $\delta \iota \varepsilon \varepsilon \kappa \varepsilon l \tau o$ $\pi o v \eta ́ \rho \omega \varsigma^{\prime \prime}$ ('he was feeling unwell'). ${ }^{20}$ According to Hägg (1994), all such techniques might be evincing a context of orality, since the average proficient reader might likely have found those redundant. Consequently, highly educated writers of early novels might have initially conceived their pieces for restricted audiences, which might have undergone some degree of expansion through orality. Along these lines, Hägg (1994) traces an addressee-ship profile of early novels as an audience still rooted in orality, concurrently not being too proficient in the reading of lengthy or complex texts.

\section{CONCLUSIONS AND DISCUSSION}

Given the worth-noting paucity of materials, research on the potential addresseeship of Ancient Greek novels needs to be approached cautiously, through contrastive techniques. As shown throughout the present paper, the study of the novelistic genre has undergone substantial change during the last decades. Prior assumptions which tended to brand novels as a "minor genre" are definitely no longer the norm. Along with this refocus, new insights have become necessary to paint an accurate - yet speculative- picture of which potential addressees might have originally been the target of the novelistic genre.

Supporting documentary evidence remains scarce, both of novelistic productions and contemporary theoretical frameworks. Of the remaining sources, most characterize the genre as some sort of a minor genre (which may slightly remind us of Catullus' self-declared nugae, 'trifles'), as opposed to other more treasured genres. We have reflected on how this was also a common reality in Ancient Greece, even from an intrageneric perspective. In the aforementioned epistle to Chariton by Philostratus, who anticipated that Chariton would never enjoy any posthumous fame whatsoever. In a historical context in which the novelistic genre constituted a major literary innovation, questions arise about who at the time would have been able to rate these literary productions in an objective manner. Many innovations throughout history have been frowned

\footnotetext{
${ }_{19}$ X. Eph. I 11 2, I 11 5, I 14 6, III 1 3, V 1 1, V 6 1, V 6 4, V 10 3, V 11 1, V 151.

${ }^{20}$ X. Eph. I 3 2, I 4 6, I 15 1, I 15 4, II 3 3, II 4 2, V 83.
} 
upon in the beginning, though eventually becoming highly valued over the centuries.

One of the paramount goals of the present paper has been that of debunking a number of flawed conceptions concerning both literary qualities of Ancient Greek novels and, relatedly, the potential community of addressees thereof. This paper has reviewed how many of these conceptions are based on anachronistic assumptions, are due to inadequate generalizations, or involve serious interpretative omissions. Also, we have tackled how history tends to paint a portrait of the Hellenistic and Imperial periods which greatly differs from that of Classical Greece. Such portrait focuses on a world ruled by individualism, a powerful urban culture, and a detachment of individuals from their original motherlands (as opposed to Classical Athenian autochthony). It is, however, when approach the geographic and societal environment of the genre that this conception demonstrates its need for ongoing revision. Relatedly, some relatively minor, quasi-embryonic political shifts have oftentimes been wrongfully regarded as an actual revolution. These include the expansion of literacy rates and the overall societal role of women. However remarkable these and other indices have turned out to be in the long run, today we know that these were barely emerging changes in the society under study. Based on the abovedeployed evidence, it is no longer feasible to consider the existence, in the Hellenistic and Imperial periods, of a widespread "book culture" or a "womenonly readership," which at the time would probably have been far from being the norm.

\section{BIBLIOGRAPHY}

BOWIE, E. (1996), "The Ancient Readers of the Greek Novels", in The Novel in the Ancient World, Schmeling, G. L. (ed.), Leiden, Brill, 87-106.

CHARITON OF APHRODISIAS (2004), Il romanzo di Calliroe, Milano, BUR. (translated by R. Roncali)

HÄGG, T. (1994), “Orality, literacy, and the 'readership' of the early Greek novel”, in Contexts of Pre-Novel Narrative: The European Tradition, Eriksen, R. (ed.), Berlin-New York, Mouton de Gruyter, 47-81.

HolzBerg, N. (1995), The Ancient Novel: An Introduction, London-New York, Routledge. Hilton, J. (2005), "War and peace in the Ancient Greek novel", Acta Classica 48, 57-85. HunTER, R. (2008), "Ancient readers", in The Cambridge Companion to the Greek and Roman Novel, Whitmarsh, T. (ed.), Cambridge [etc.], Cambridge University Press, 261-271. KNOX, B. M. W. (1968), "Silent reading in antiquity", GRBS 9, 421-35.

MORGAN, J. R. (1995), "The Greek Novel: Towards a sociology of production and reception", in The Greek World, Powell, A. (ed.), London-New York, Routledge, 130152.

PERRY, B. E. (1937), "The early Greek capacity for viewing things separately", Transactions and Proceedings of the American Philological Association, 403-427.

PlePELITS, K. (1976), Chariton: Kallirhoe, Anton Hiersemann, Stuttgart. 


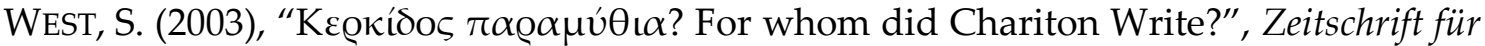
Papyrologie und Epigraphik 143, 63-69.

XENOPHON OF EPHESUS (1967), Efesíaques, Barcelona, Fundació Bernat Metge. (translated by C. Miralles)

WhITMARSH, T. (2001), "'Greece is the World': Exile and identity in the Second Sophistic", in Being Greek under Rome: Cultural Identity, the Second Sophistic and the Development of Empire, Goldhill, S. (ed.), Cambridge, Cambridge University Press, 269-305. 